\title{
COHESION IN SPANISH AS A SECOND LANGUAGE IN AN INDIGENOUS SCHOOL ${ }^{1}$
}

\author{
Cohesión en español como segunda lengua en un colegio indígena
}

Lina Katerine Amaya Pérez

lamayap@unbosque.edu.co

\section{Mario Santiago Fonseca Parra mfonsecap@unbosque.edu.co}

Juan Esteban Pineda Guarín

jpinedag@unbosque.edu.co

Received: January 16, 2019

Accepted: February 12, 2019

How to cite this article:

Amaya, L. K., Fonseca, M. S., \& Pineda, J. E. (2019).

Cohesion in Spanish as a second language in an indigenous school. Enletawa Journal, 12(1), 14-38.

\begin{abstract}
This qualitative action research study analyzed the effect of Task Based Learning (TBL) through meaningful materials in the writing process of Spanish as a Second Language (SSL) for fifth graders from a Sikuani indigenous school located in Puerto Gaitán, Meta, Colombia. Throughout the sessions, task included different materials and games, such as a linguistic roulette, in order to help students foster cohesion when writing in Spanish as a second language. The instruments used to collect data were students' artifacts (narrative texts), field notes, and semi-structured interviews. The results obtained showed that after the implementation, students were able to write short sentences using the parts of speech, such us articles, nouns, and verb conjugations, accurately according to Spanish grammar.

Key words: Spanish as a second language, L2 literacies in indigenous communities, written cohesion in Spanish, Task Based Learning (TBL)
\end{abstract}




\section{Resumen}

Esta investigación de acción de corte cualitativo tiene el objetivo de analizar el efecto del Aprendizaje Basado en Tareas (TBL) a través de materiales significativos en el proceso de escritura de Español como Segunda Lengua (ESL) en estudiantes de quinto grado de una escuela indígena en la comunidad Sikuani ubicada en Puerto Gaitán, Meta, Colombia. A lo largo de las sesiones, se implementaron tareas que incluían diferentes materiales y juegos - como una ruleta lingüística- con el fin de ayudar a los estudiantes a fomentar la cohesión al momento de escribir en español como segunda lengua. Los instrumentos utilizados para recopilar datos fueron artefactos de los estudiantes (textos narrativos), notas de campo y entrevistas semiestructuradas. Los resultados obtenidos mostraron que después de la implementación, los estudiantes pudieron escribir oraciones cortas utilizando las partes del discurso cómo artículos, sustantivos y conjugaciones de verbos de una manera más adecuada de acuerdo a la gramática del español.

Palabras clave: Español como segunda lengua, alfabetización de L2 en comunidades indígenas, cohesión escrita en Español, aprendizaje basado en tareas. 


\section{Introduction}

According to the Colombian Ministry of Culture (2010), Sikuani people are an indigenous group with the greatest territorial presence in the Colombian Orinoquía. This ethnic group is located in the eastern plains of Colombia, specifically between Meta (north), Vichada and Guaviare (south), Orinoco (east), and Manacacías (west) rivers. Taking into account the previous idea, this action research focuses on the Wacoyo reservation located in Puerto Gaitán, Meta, where there are approximately four hundred families housed in 34 different communities that constitute the whole territory.

According the National Work and Concertation Commission on Education for the Indigenous People, or CONTCEPI, the Sikuani educational system, as well as in all the ethnic groups in Colombia, visibly makes an effort to maintain their mother tongue while including Spanish to communicate with non-indigenous people (2013).
Correspondingly, the phenomenon of understanding and speaking two different languages is denominated bilingualism (Blázquez, 2010). In the particular case of the Wacoyo reservation, Sikuani and Spanish are correlated languages depending on the setting. Sikuani is spoken to communicate with family, friends, and the community. On the other hand, Spanish is used to communicate in official contexts, such as school and church.

Taking into account that the linguistic features between Spanish and Sikuani languages are different, it is difficult for students who speak Sikuani to transpose what they think and want to say into written Spanish. As Vigil (2006) stated regarding indigenous languages, Sikuani is preliterate, meaning it is is barely written, as opposed to Spanish, which has a well-developed writing skill. In terms of cohesion, students faced difficulties at the moment of implementing an appropriate use of syntax in L2 when 
writing, which triggered the lack of coherence in their written sentences.

The identified problem was visible through a teaching practicum carried out in Kuwei School, inside the Wacoyo community. At the beginning, we noticed that most of the students were suffering from a lack of cohesion in activities that required them to write down sentences in the L2. In these written activities, students were asked to write about their culture and their beliefs, which allowed us to diagnose some common mistakes in students' artifacts related to nouns, gender, and verb conjugations.

After identifying this problem, we implemented Task Based Learning (TBL henceforth) through meaningful material called "linguistic roulette" as an answer to this situation. Bearing in mind that our focus was on written production, we chose this methodology since it followed clear steps (pre-task, task preparation, task realization, and post-task). According to Richards and
Rodgers (2004), "engaging learners in task work provides a better context for the activation of learning processes" (p. 223). These authors affirmed that the negotiation of meaning in TBL provided the input and output necessary for language acquisition (Rodríguez \& Rodríguez, 2010). The above could help implement our strategy since the steps taken during the classes complemented the use of the "linguistic roulette". In other words, TBL did not just help us identify students' mistakes, but it also improved their written fluency and cohesion in Spanish. Hence, we analyzed how the TBL methodology promoted further solutions to the lack of cohesion in written practices in $\mathrm{L} 2$ by implementing meaningful materials.

\section{Research Question and Objective}

What is the impact of implementing TBL through meaningful Spanish as a Second Language materials in the writing process of fifth graders from a Sikuani indigenous community? 
To analyze the effect of TBL through meaningful Spanish as a Second Language materials in the writing process of fifth graders from a Sikuani indigenous community.

\section{Literature Review}

For this project, we considered several theoretical sources and constructs that help support our research process. The two constructs that are presented in this research article are: Bilingualism and Spanish as a second language and written cohesion in L2. These concepts form the basis of our project since they are visible phenomena that we found at Kuwei School.

\section{Bilingualism and Spanish as a Second}

\section{Language in Indigenous Communities}

Bilingualism is a phenomenon that is perceived inside the classrooms of Kuwei School. Two languages coexist as a way of communication: Sikuani and Spanish. According to Blázquez (2010) and Alarcón (2007), bilingualism is the ability that a person has in two different languages to express their ideas, without the same fluency, in an appropriate and effective way in different communicative contexts. However, there are two types of bilingualism, which are compound and coordinated. Both are handled by indigenous children inside the classroom (Trillos, 2002). Some of them dominate the compound one, whilst the others control the coordinated one when using Spanish as a second language. In this section, the definitions of the two types of bilingualism are described, as well as the concept of Spanish as a second language (SSL) and how these phenomena theoretically contribute to this research study.

To begin, it is essential to define the concepts of coordinate and compound bilingualism and how children use them inside the classroom. Trillos (2002), as cited in Gutierrez (2013), stated that coordinated bilinguals maintain two independent systems, and when they receive a message in Spanish 
or in the indigenous language, they assimilate it and produce the answer in the same language. Whilst, for compound bilinguals, one of the languages dominates over the other one. For that reason, when they receive a message in Spanish, they understand and respond in the same language (L2). However, when a compound bilingual receives a message in the indigenous language (IL), he or she translates it into Spanish and elaborates the answer in the same language. Finally, they translate and broadcast it in the indigenous language. As such, understanding these two types of bilingualism inside the classroom at the Kuwei Primary School is relevant for us to better comprehend bilingualism in this educational institution.

Among Colombian indigenous communities, Spanish facilitates communication within the academic and official fields. Based on Alarcón (2001) and Alarcón (2007), Spanish is conceived by different indigenous societies as the language that allows them to communicate with other communities and with non-indigenous people in different contexts. Where we carried out our study, Spanish is a way of communicating with official contexts, such as politics and business, and with nonindigenous people. Thus, Spanish is a way to remain in contact with other dominant cultures.

In order to define the concept of second language, particularly Spanish, and how it is adopted among different sectors, Bordon (2015) argued that "a second language is widely adopted as a means of communication in certain sectors (government or education) and that coexists with other languages within the context" (p. 31). This statement is significant for our research since it clarified why Spanish has been implemented in this context and spoken in educational fields. Furthermore, Bordon (2015) claimed that Spanish is a language that fulfills two specific functions. The first function is to the right to 
bilingual education among all Colombian students. The second is to raise a student's education level before entering an institution of higher education.

The Own Indigenous Educational System or Sistema de Educación Indígena Propio SEIP (2013) is one of the main educational policies for the indigenous communities in Colombia. It was developed with CONTCEPI (2013), and it adapts Spanish within the indigenous social groups. This educational proposal was created as "A defense mechanism with the objective that indigenous people advance in the reflection and debate on the construction, development, strengthening, and consolidation of the educational field" (SEIP \& CONCEPI, 2013, p. 8). Therefore, this document is relevant for indigenous communities because they it is a fundamental strategy for the permanence of indigenous cultures in Colombia. On the other hand, it is crucial to take into account the voice of indigenous groups about what
Spanish means to them. In regard to the teaching Spanish as a second language, CONTCEPI (2013) considered "to learn Spanish in order to communicate with nonindigenous people. Nevertheless, it has been used for the defense of culture and rights in the process of indigenous struggle."(p. 25). Thus, SEIP (2013) has allowed Spanish to become a way for indigenous people in Colombia to defend their culture against the different aspects that affect their survival.

In conclusion, Spanish is considered as an important means of communication within bilingual indigenous contexts. Indeed, indigenous communities have established their own reasons to implement Spanish in their societies. In this indigenous community, Spanish is the means through which they establish communication with nonindigenous people. Also, it enhances the educational levels that students must face. Taking into account that Spanish and Sikuani are the two languages spoken in this society, 
there are two types of bilingualism that can be perceived inside the classrooms of Kuwei School: compound and coordinate. Moreover, some students dominate compound bilingualism, whilst others dominate the coordinate one. Thus, contemplating on this phenomenon would give us a clear idea about the impact that it has on the students' educational processes.

\section{Written Cohesion in Spanish}

Cohesion in Spanish as a Second language is an important issue because it aids in proper written communication in the L2. In fact, Huerta (2010) argued that text linguistics takes into account the aspects of textual coherence and cohesion that make up the matrix of meaning within a text. When we write in Spanish, we infer the relevance of cohesion as when we convey meaning. In this final portion of the literature review, we will highlight the definition of cohesion as expressed by two different authors. In addition, we look at how this construct applies to our research study.

In writing narrative texts, word order within a sentence matters, and the writer should pay attention to it. Before defining cohesion, it is important to mention that there are some textual and linguistic criteria, two of which are cohesion and coherence (Beaugrande \& Dressler, 1997). According to Medina and Arnao (2013), cohesion is a functional element of the textual microstructure. It consists of the sentence sequences that make up the textual surface interconnected with grammatical aspects, such as repetition, pronominal forms, coreference, elision, and connection. In other words, each word that is used in a sentence will help provide meaning. Grammar interconnection also allows for better communication in a written way when sequences are connected. Medina and Arnao (2013) added the following, Cohesion represents the 
communicative function of syntax.

This is not only a set of superficial relationships that grammatically interconnects the various textual components, but each linguistic element directs and mediates the operation of access to other linguistic elements with which it interrelates. (p.

Therefore, word connection should definitely matter since it mediates the linguistic process in any written exercise, thereby, triggering meaning and coherence.

Writing cohesively in Spanish can also help students reach their academic and personal goals. Medina and Arnao (2013) stated that after students read significant texts, they were able to perform specific drafting procedures that respected the textual properties that make up speech. Hinkel (2004) argued that "current L2 pedagogy deals with matters of text cohesion in various ways. Teaching of $\mathrm{L} 2$ reading often seeks to address logical connectivity and flow of ideas in discourse and matters of organization in text progression" (p. 112). Cohesion contributes to our research process because it clarified the relevance of considering Spanish syntax among our population. Therefore, students can fulfill deeper communication of their thought and beliefs through a written structure.

It is essential to highlight how bilingualism, and especially Spanish as a second language, has had a huge impact within the Wacoyo community by connecting them with non-indigenous people. Consequently, this has led to an effort to enhance writing skills in the L2 in order to manage this skill in Spanish more effectively. Thus, we show how these constructs built the basis of our research project and gave way to our methodology to find an answer to the problem. 


\section{Research Design}

In this section, we will explain the type of study, population, context, ethical considerations, data collection instruments, and pedagogical implementation.

This is a research project that follows the qualitative approach. Creswell (2009) stated that:

Qualitative research is an approach for exploring and understanding the meaning individuals or groups ascribe to a social or human problem. The process of research involves emerging questions and procedures, data typically collected in the participant's setting, data analysis inductively building from particulars to general themes, and the researcher making interpretations of the meaning of the data. (p.32)

Using a qualitative approach helped us represent the research problem as it was represented within an educational context of fifth graders. We also considered using action research to carry out our study. Mills (as cited in Creswell, 2012) stated that action research can be systematic and carried out by the teachers themselves or others in the educational field. Additionally, action research can help in improving teaching and learning practices, as well as the educational setting. Hence, we aimed to implement a methodology that would help in solving the problem in our context.

\section{Context and Population}

This action research was carried out in an indigenous school called Kuwei, located in the middle east of Colombia. To be more exact, we worked within a community called Wacoyo in Puerto Gaitán, Meta. This location has an elementary and secondary school, where there are approximately 330 students in secondary and 330 in primary levels. Kuwei is the biggest public school within the Sikuani community, and there are 12 primary school branches around the 
territory (Walabo, Corocito, El Vergel, La

Hermosa, Yoluwa, La Seiba, Walabo 2, Manguito, Guamito, Chaparral, Fundo Bonito, and Yopalito). In this community, two languages coexist, where Sikuani is their mother tongue and Spanish is the second language. This research focused on fifth graders in Kuwei School, where 40 students are indigenous, 13 students are mestizos $^{2}$, and two students are white. In this group, there are 55 students. Fifth graders' ages are usually between 10 and 12 years old in Colombia, but in this case, the students were between 8 and 17 years old.

\section{Instruments for Data Collection}

We selected students' artifacts, field notes, and video recordings as our data collection instruments. Students' artifacts, such as journals and letters, facilitated access to students' language use in the written exercises (Creswell, 2009). Consequently, the teachers' field notes helped us perceive

2 (In Latin America) a person of mixed race, especially one having Spanish and indigenous uncommon features in the class through observation (Creswell, 2009). Video recordings helped us recognize what the students believed about their own process and problems faced in the classroom. For instance, we could observe their lack of cohesion in speaking, and consequently, in their writing productions. Finally, the implementation of these instruments gave us a better understanding of the situation that our students faced in terms of cohesion.

\section{Pedagogical Implementation}

The methodology that was part of the instructional design for this action research was task-based learning (TBL). Willis and Willis (2007) stated that "a good task not only generates interest and creates an acceptable degree of challenge, but also creates opportunities for students to experiment and activate as much language as possible" (p. 70). Considering the focus is on writing, TBL 
can not only detect learner's confusion, it can also strengthen their written fluency and cohesion in Spanish. Therefore, the thematic basis of this project will focus on three main topics: nouns, articles, and tenses. These topics were selected based on the most notable mistakes observed in the students' written texts written during the diagnostic stage of the study.

The strategy we chose was a "linguistic roulette", which had three aspects. First, as it is a didactic game, it attracts the attention of the students. Second, it was age appropriate. Finally, it gave students the opportunity to practice the Spanish linguistic categories they learnt during class time. Through this material, students had the possibility to activate the writing process in the L2. In addition, the process followed the Task-Based Methodology Framework consisting of pre-task, task preparation, task realization and post-task. First, the pre-task stage consisted of activating prior knowledge in the students before explaining it. Second, task preparation recycled language and familiarized students with the context as much as possible (Willis, 2007). With this concept in mind, students were able to use linguistic roulette and practice the topics learned. Third, in task realization, the students produced, executed, and presented their tasks that were explicit in the meaningful material. Finally, we evaluated and gave students feedback in the post-task in order to reflect on accomplishments and correct errors (Willis \& Willis, 2007).

In addition, Van den Branden (2006) explained how in the investigation of second languages, the tasks have been used to study the linguistic production, interaction, and negotiation of meaning in order to improve the acquisition of second languages. Therefore, TBL has an important role in improving the written cohesion of students of Spanish as a second language. Van den Branden (2006) also explained what a task is 
and defined it as "an activity in which a person commits to achieve an objective, and which requires the use of language" (p. 4). In the case of fifth grade students, our objective was for the students to write cohesively in the L2, using "linguistic roulette" as didactic material.

\section{Data Analysis and Findings}

This action research project demonstrated the results of a task-based learning activity in a didactic implementation at an indigenous Sikuani school called Kuwei. At this school, the fifth graders failed to write properly in Spanish since most of them were confused with basic Spanish grammatical rules. In other words, our target population lacked cohesion in their Spanish texts due to confusion in gender articles based on the noun. Likewise, we found that some of them presented mistakes at the moment of using verbal structures accurately, which is the reason why we used meaningful material. We were aware of our population's age, so we sought to develop ideas that would be ideal for them to enhance their cohesion in Spanish in regard to article, verb, and gender noun complement.

In order to collect data, we used three instruments: field notes, interviews, and artifacts to understand the students' processes and development during the roulette. Based on the data, we carried out a triangulation process, which according to Yeasmine and Ferdousour (2012), “is a process of verification that increases validity by incorporating several viewpoints and methods" (p. 156). Therefore, we found two main aspects that are mentioned in two different categories. The first one is concordance between nouns and articles in terms of gender, and the second is cohesion in verbal conjugations. 
Concordance Between Articles and Nouns in Terms of Gender

When attempting to write more cohesively in Spanish, it is necessary to complement the articles and nouns. This could help students identify whether the noun or article is masculine or feminine, as well as develop clarity in their texts. According to Nieto (2011) "In the Spanish language, all nouns have always gender. It is very important to know if a noun is masculine or feminine to establish concordance with the nominal elements that are converted to it (articles, adjectives and pronouns)" (p. 2).

Because of the previous and the implementation of the Task-Based Learning activity during class, we identified some indicators that the students were progressing in their written productions. For instance, they correctly used complete sentences in a narrative text while complementing the articles and the nouns properly. In the following paragraphs, we present the information that we collected through interviews, field notes, and artifacts. The data illustrates the students' advances in applying proper concordance between articles and nouns in terms of gender. Likewise, this led to a more understandable texts in Spanish.

Throughout the data, we noticed that the students tend to make mistakes when selecting the correct article and noun to use in their texts. The following excerpts demonstrate the initial difficulties students had in choosing the right article and noun before implementing our strategy and their progress afterward.

\section{BEFORE}

\section{Excerpt 1 (Artifact 1)}

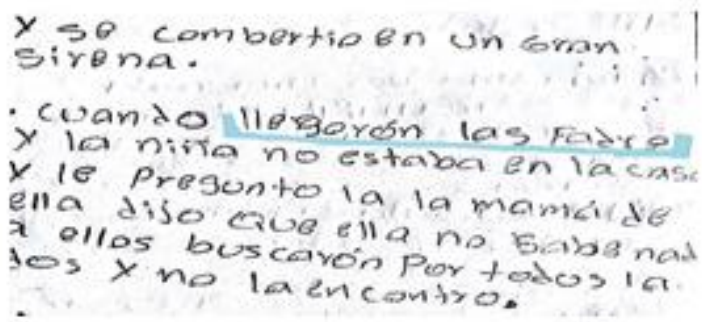

"1legarón las padre" (A1S2) 


\section{AFTER}

\section{Excerpt 2 (Field Notes 1)}

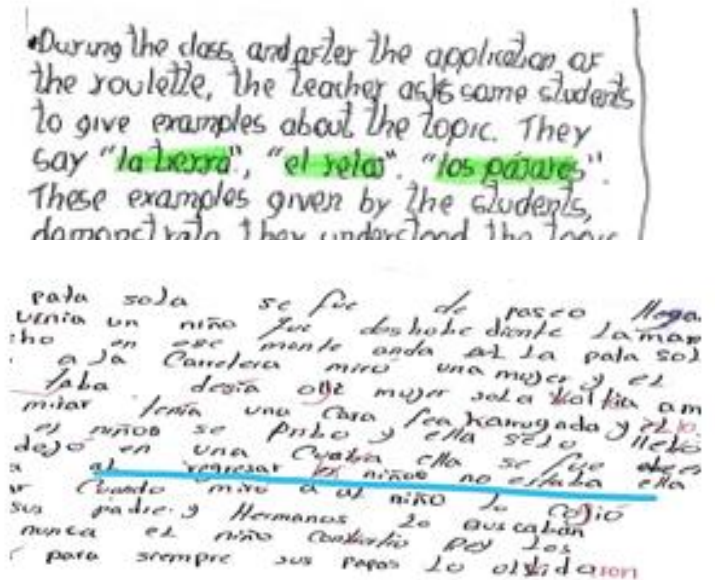

"al regresar la niños no estaba ella" (A1S8)

As seen in the previous excerpts, the students had problems when selecting the correct article or noun before the implementation of the roulette. Nonetheless, after its application, the learners demonstrated progress in their written texts. In Excerpts 1 and 3, we noticed that the students combined the articles and nouns, disregarding whether they were masculine or feminine. For example, the students said "las padre" and "la niños" (see Excerpt 1) and "la árbol" (see Excerpt 3). Therefore, the data

\section{Excerpt 3 (Interview 1)}

E: ¿Sí? ¿Qué más te pasa? Así que tú digas "se me dificulta tal cosa"...

\section{S9: "La árbol" (I1S9-Min-02:02)}

E: ¿La árbol? ¿Tú usualmente dices "la árbol" y te confundes?

S9: asiente con la cabeza

collected before the implementation of the strategy demonstrated a lack of cohesion in Spanish due to mistakes in concordance. After its implementation, the students were able to properly use the concordance between these grammatical categories (see Excerpt 2). As Yang (2015) indicated,

It is natural that knowing whether a noun is masculine or feminine does not necessarily imply a correct production of it and other concorded forms, since in order to achieve this it is necessary to correctly produce all the concordant elements at the same time. (p. 197) 
According to the previous

information, we saw that the students

produced the concordant elements in a sentence, which means they progressed in selecting the correct articles and nouns after the implementation of the roulette. This was also witnessed in the following excerpt:

\section{BEFORE}

\section{Excerpt 4 (Field Notes 1)} * Is the class berore the molementation mistakes that evidence the lack of concordance in Spanish. The Zeacher asks some learners to give a sentence for her 20 write on the board and they say "ila cuaderno rojo" and "las árboles grandes": which means ther confuse theggender in spanish.

"la cuaderno rojo", "las árboles grandes"

\section{AFTER}

\section{Excerpt 5 (Field Notes 2)}

* During an adivity in which students
have to create sentences on ther
notebooks, a student ( 55 ) asks if
what she wrote is coryect. The
teacher perceived that the student
wrote "la ranoa de madera" which
means she did a proper example.

"la canoa de madera"

\section{Excerpt 6 (Artifact 2)}

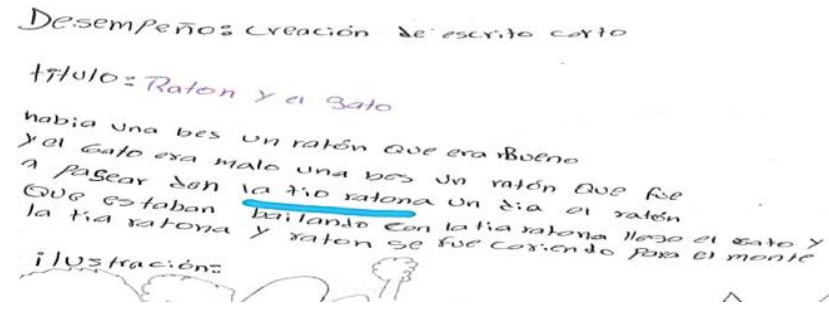

"la tio ratona" (A2S2)

\section{Excerpt 7 (Artifact 2)}

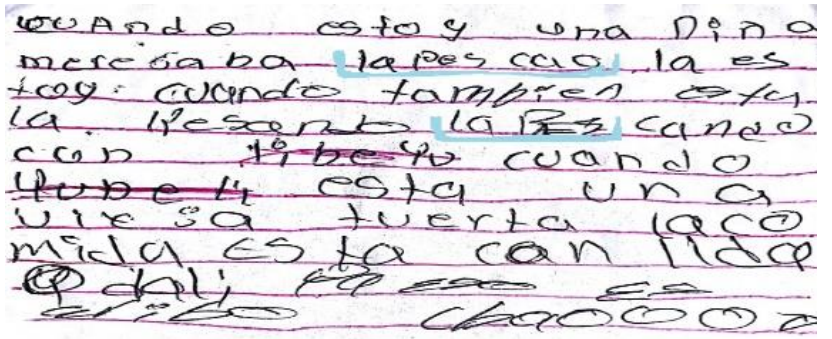

"la pescao" "la pez" (A2S5)

During the classes, we noticed that the

students had difficulties in identifying gender in articles and nouns before implementing the strategy. However, after the application of the linguistic roulette, some of the pupils presented grammatical progress. As shown in the Excerpt 4, the students confused the gender of the article and noun. Because of this, the learners were unable to express their ideas adequately in Spanish. Moreover, they were unaware of the importance of gender 
concordance in the Spanish language, as indicated by RAE (2009), which states that "Regarding gender, nouns are classified as masculine and feminine. With many nouns that designate animated beings, the gender serves to differentiate the sex from the referent" (p. 24). Consequently, after the application of the strategy, some students could recognize the importance that gender concordance had in the Spanish language. Additionally, they were able to appropriately use concordance between articles and nouns, as visible in Excerpt 5. Despite, the implementation, some students were still unable to differentiate the correct gender concordance, such as in the case of Excerpt 6 and 7. Nonetheless, the students improved for the most part in identifying the correct gender of the article and noun.

To conclude, we noticed that the application of the linguistic roulette during the classes contributed to better understanding how the students selected gender concordance based on the noun and article. During the first classes, the learners presented several difficulties that did not allow them to make proper use of gender concordance when writing. Moreover, the students were unable to identify whether a noun or article was masculine or feminine in their own texts. After the implementation of the strategy, some of the students appropriately applied concordance between the grammatical elements mentioned previously. Therefore, the execution of the linguistic roulette helped the students with their written productions.

\section{Cohesion in Verbal Conjugations}

Different weaknesses are present when learning a second language and producing written texts. One of these weaknesses is grammatical conjugations. According to DiFranco (2007), "the learning of the verbal flexion of a language such as Spanish is one of the most important 
difficulties when it comes to acquiring a good command of that language for all learners" (p. 1). In our findings, we witnessed that our students were unable to conjugate verbs. In part, this was because they did not know what "conjugation" meant, so they were unable to create cohesive texts. In this section, we will present some of the samples collected during the Spanish classes to demonstrate the students' initial difficulties in terms of cohesion in verbal conjugation. Additionally, we present their improvements with the help of the linguistic roulette.

Within the chosen population, we discovered that the students had difficulty in conjugating verbs with their noun or pronoun. Austin (1962) and Searle (1969) (as cited in Rodriguez \& Quintrileo, 2016) stated that "from the pragmatic plane, the conjugated verb encloses the action aimed at obtaining of concrete purposes. From the theory of speech acts, verbal action is a characteristic of the realizing verbs, which carry the intention or communicative purpose" (p. 141). Taking into account what we found during the classes, the students could not conjugate verbs appropriately. So, they could not obtain the communicative purpose that they needed to express. Accordingly, their goal of communicating an idea in a written way was distorted. In brief, written cohesion was not possible because the learners dd not have an understanding of verbal conjugations.

In the following excerpts, we noticed that at first the students could not conjugate the verbs correctly. As mentioned before, this hindered their creation of cohesive texts. In addition, the students were unaware of the time, place, and action when conjugating verbs. In this way, we collected data through field notes, interviews, and students' artifacts in order to understand their lack of cohesion. The first excerpt represents the students' work before the implementation of the linguistic roulette, which is followed by the 
results of the pedagogical intervention.

\section{BEFORE}

\section{Excerpt 8 (Field Notes 1)}

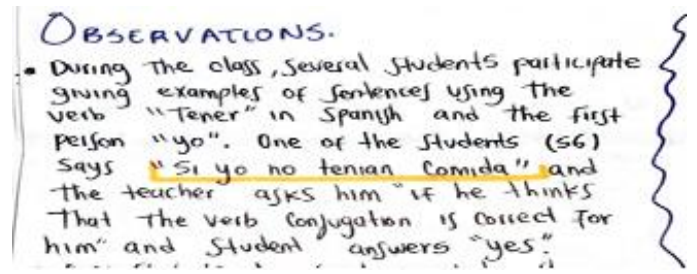

"si yo no tenían comida"

\section{Excerpt 9 (Artifact 1)}

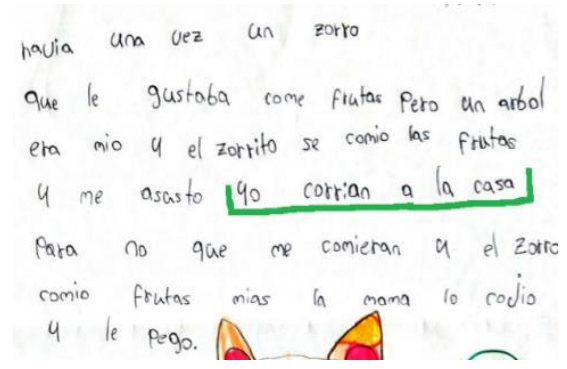

"Yo corrian a la casa" (A1S7).

\section{AFTER}

\section{Excerpt 10 (Field Notes 2)}

* In Zhis class studants use "lisouistic roulette" applying the theme that the teachpr already explained that is varbal covusations A sivdent (S3) goes in Front os the class and the teacher asks him what he usually and the leacher asks him what he usually
does at recess, the child answers "yo carro en el recspo" and writes in an the board correctly. In that way, the student respands appropriately using the, verb, "corser". . .

"Yo corro en el recreo"

\section{Excerpt 11 (Artifact 2)}

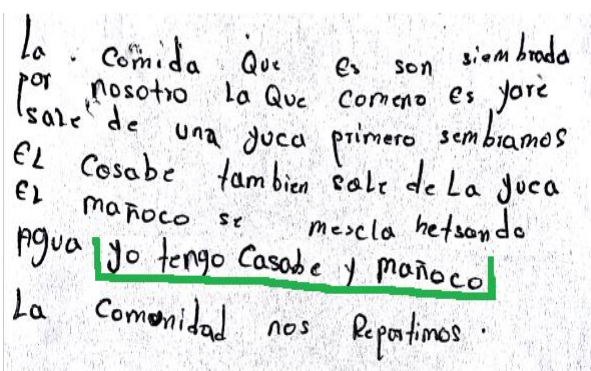

"Yo tengo casabe y mañoco" (A2S8)

As we can see in the previous excerpts, the students could not write sentences that were appropriately conjugated in the first-person. Because of this, there was a lack of cohesion in Spanish among L2 learners. Before using the linguistic roulette, the students would say "si yo no tenían comida" (see Excerpt 8) or they used to write "Yo corrian a la casa" (see Excerpt 9). Bearing this in mind, Alarcos (2003) stated that "it is said that the verb carries the first person when the speaker actually coincides with the entity to which the grammatical subject refers" (p. 139). According to the above, the students were not clear about the grammatical subject, and therefore, used the past of the verb "correr" conjugated in the 
plural form. However, the correct way would

have been in its singular form since the first

person was used. As the classes progressed

and the linguistic roulette was taking place, it

was evident that the students were able to

create sentences using verbal conjugations

with the first person in an appropriate way.

This is seen in Excerpts 10 and 11 in which

the students wrote "yo corro en el recreo"

(Excerpt 2...) and "Yo tengo casabe y mañoco". Based on the data, we could see

that the students had improved on their use of

verbal conjugations, resulting in a

breakthrough in their written cohesion of the

L2.

In addition to first person verbal

conjugation issues, the students were also

confused about the third person. The

linguistic roulette served as an instrument to

practice articles, nouns, and verbal

conjugations. In the case of verbal

conjugations, the students could turn the

roulette and conjugated the verb and wrote sentences depending on the number that

came out. In addition, they could learn and

enhance their writing while playing. In the

section that follows, we compared the before

and after the application of the linguistic

roulette.

\section{BEFORE}

Excerpt 12 (Field Notes 1)

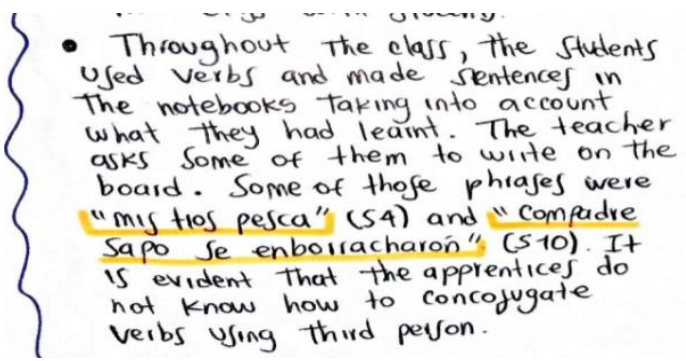

"mis tíos pesca" "compadre sapo se

enborracharón"

\section{Excerpt 13 (Artifact 1)}

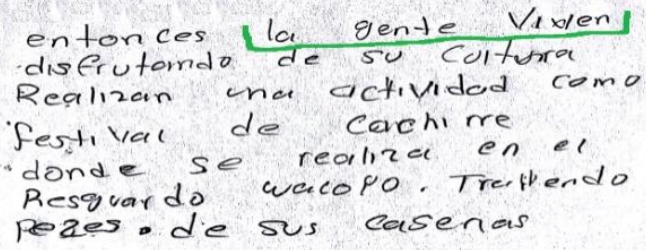

"la gente viven" (A1S1)

\section{Excerpt 14 (Artifact 1)}




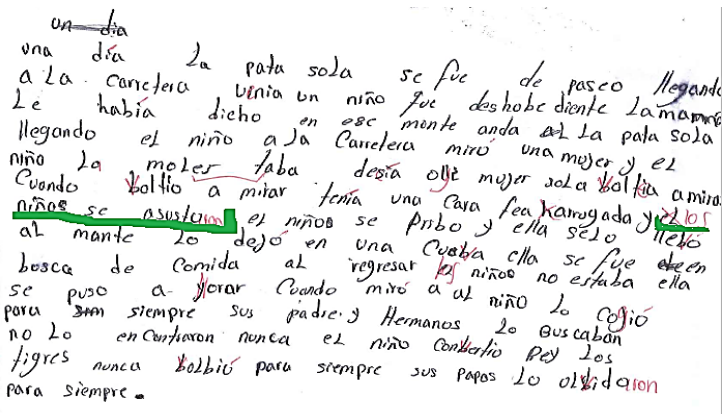

"los niños se asusta" (A1S8)

\section{AFTER}

\section{Excerpt 15 (Artifact 2)}

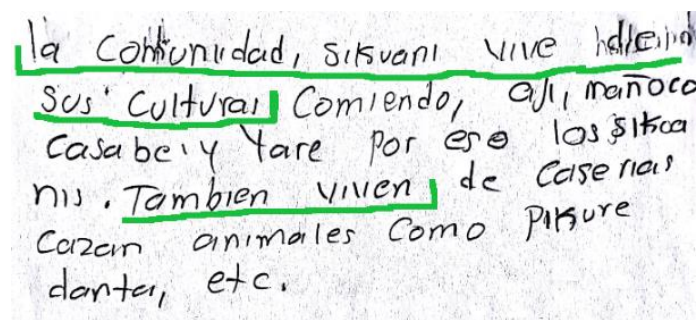

"La comunidad, Sikuani vive de sus culturas" (A2S1)

\section{Excerpt 16 (Artifact 2)}

$$
\begin{aligned}
& \text { Titulo: La reina yel sapo } \\
& \text { Habia una ves unareina que vivió } \\
& \text { en los bosques ella es taba } \\
& \text { moy contenta y al atro rato } \\
& \text { Se encontró con un sapo } \\
& \text { y el sapo se enamoró }
\end{aligned}
$$

"Habia, vivió, estaba, encontró, enamoró"

Excerpt 17 (Interview 1)
T: ¿Cuál es el verbo en la oración "El perro come carne"?

\section{S3: "Carne es el verbo" (I1S3-Min-01:02)}

T: ¿En qué tiempo está la oración anterior?

\section{S3:"verbo pasado" (I1S3-Min-01:20)}

T: ¿En qué tiempo está la oración "Yo manejé el carro"?

S7: "Presente" (I1S7-Min-01:01)

\section{Excerpt 18 (Interview 2)}

T: Quería preguntarte, ¿cómo te fue ahí con la actividad, la estrategia didáctica?

S6: ¿Hm?

T: ¿Cómo te fue con la estrategia didáctica, con el juego? (I

\section{S6: Sirvió. (I2S6-Min-01:03)}

T: ¿Sí? ¿Te gustó?

S6: Si.

T: ¿Cómo te sentiste ahí con esa actividad?

T: Pues bien porque ya sabía lo que yo

tenía que hacer. (Min 01-33)

T: ¿Ah, sí? ¿Y a ti qué te tocó hacer?

S6: Pues de unos artículos que... 
sustantivos...

T: Okey. ¿Y qué oración hiciste tú?

S6: Hm... esto... el perro comió carne.

(Min- 01-55)

T: El perro comió carne.

S6: Sí.

T: ¿En qué tiempo está esa oración? El perro comió carne...

S6: Pasado. (Min- 02-04)

During the Spanish as a Second Language classes, the students incorrectly conjugated the verbs in the first and third person. Alarcos (2003) argued that "it is considered that there is a third person when the real reference of the grammatical subject does not coincide neither with the speaker nor with the listener" (p. 139).

According to the previous stance, it is possible to affirm that the students were confused about choosing the subject and verb agreement. However, before using the strategy they wrote such things as "compadre sapo se enboracharón" (see Excerpt 12) or "la gente viven" (see Excerpt 13). These sentences demonstrated the inappropriate use of third person and verb agreement. After applying the strategy, they could write "La comunidad, Sikuani vive de sus culturas" or "Habia, vivió, estaba, encontró, enamoró" (see Excerpts 15 \& 16), thereby using verbs properly. In the same way, it was evident that the learners did not know what the verb was in the sentence, such as in the case of "Carne es el verbo" (see Excerpt 17). Therefore, this confusion led to further lack of cohesiveness. However, they were able to notably improve in terms of writing after the implementation of the linguistic roulette. Additionally, cohesion in verb subjective agreement improved as the classes progressed.

\section{Conclusions}

To conclude, Kuwei fifth graders enhanced their written texts in Spanish when meaningful material based on a TBL 
approach was implemented. Even though

Sikuani was their first language, they were also able to communicate in their second language by practicing their written skills. In this case, this was carried out through a linguistic roulette as a strategy to foster writing cohesion.

Throughout the process, the students had significant improvements in their writing in Spanish, particularly in regard to verb conjugations and gender concordance between noun and article. In terms of verb conjugations, the students initially confused the verbs depending on the tense. After applying the strategy, they started to conjugate the verbs correctly in the first and third person. Additionally, the Kuwei fifth graders interpreted the concordance between article and noun incorrectly. As the classes progressed and the linguistic roulette was implemented, their written fluency increased. They began consistency apply the correct concordance between these grammatical elements. Finally, although this action research was focused on written production in Spanish as a Second Language within a Sikuani indigenous community, it opens up the opportunity of doing more research geared towards the production field of this language.

\section{References}

Alarcón, W. (2001) Elementos para un diagnóstico sociolingüístico de La Pedrera, Amazonas. Trabajo de Maestría. Bogotá: Universidad Nacional de Colombia. Facultad de Ciencia Humanas, $80 \mathrm{p}$.

Alarcón, D. (2007). Bilingüismo indígena en Colombia. GiST Education and Learning Research Journal, (1), 24-38.

Alarcos, E. (2003). "Nueva Gramática de la Lengua Española, de Emilio Llorach y la Real Academia Española" (Colección Nebrija y Bello)

Austin, J. (1962). How to do things with words. London, UK: Oxford University Press.

Beaugrande, R. \& Dressler, W. (1997). Introducción a la lingüística del texto. Edit. Gedisa. Barcelona. 
Blázquez, A. (2010). Análisis del Bilingüismo. Innovación y Experiencias Educativas.

Bordón, T. (2015) La adquisición del español como segunda lengua en las aulas de primaria: Una reflexión. Universidad Autónoma de Madrid. Retrieved from file:///C:/Users/Usuario/Downloads/ DialnetLaAdquisicionDelEspanolCo moSegundaLenguaEnLasAulas4638277.pdf

Comisión Nacional De Trabajo Y Concertación De La Educación Para Los Pueblos Indígenas- Contcepi, (2013). Perfil Del Sistema Educativo Indígena Propio- S.E.I.P Retrieved from

http://www.caminosinterculturales.or g/documentos/Debates-

Pedagogicos/Pedagogia-propia/Parair-mas-alla/SEIP.pdf

Creswell, J. (2009). Research design: Qualitative, quantitative, and mixed methods approaches. Los Angeles, CA: Sage.

Creswell, J. (2012). Educational research: Planning, conducting, and evaluating Quantitative (4 ${ }^{\text {th }}$ ed.).

University of Nebraska-Lincoln.: Pearson/Merrill Prentice Hall.

DiFranco, C. (2007). Los errores de morfología verbal en la adquisición de la selección modal indicativo/subjuntivo por parte de estudiantes italianófonos de E/LE.

Gutiérrez, C. (2013). Tejido bicognoscitivo \& bicultural; contribuciones para la enseñanza del español como segunda lengua en la escuela San Rafael, resguardo Domoplanas.
Hinkel, E. (2004). Matters of cohesion in L2 academic texts. Seattle University, WA. Retrieved from http://www.elihinkel.org/downloads/ Cohesion.pdf

Huerta, S. (2010). Coherencia y cohesión.

Herencia: Estudios literarios, lingüísticos y creaciones artísticas, 2(2), 76-80.

Medina, I. \& Arnao, M. (2013). Coherencia $y$ cohesion en el discurso escrito de estudiantes universitarios. Universidad César Vallejo, Chiclayo - Perú. Retrieved from http://www.redalyc.org/pdf/5217/521 752180007.pdf

Mills, G. E. (2011). Action research: A guide for the teacher researcher ( $4^{\text {th }}$ ed.). Boston, MA: Pearson

Ministerio de Cultura - República de Colombia. (2010). Sikuani, entrañables defensores de su territorios. Retrieved from: http://www.mincultura.gov.co/areas/ poblaciones/noticias/Documents/Car acterizaci\%C3\%B3n\%20de1\%20pue blo\%20Sikuani.pdf

Nieto, G. (2011). El sustantivo español:

Algunas consideraciones pertinentes para los profesores de español como lengua extranjera. Lenguas en contacto y bilingüismo: Revista digital, (3), 1-20.

Real Academia Española. (2009).

Diccionario de la lengua española (22th ed.). Retrieved from http://www.rae.es/rae.html 
Richards, J. \& Rodgers, T. (2004). Approaches and methods in language teaching. Cambridge, UK: Cambridge University Press.

Rodríguez, B. \& Rodríguez, J. (2010). Taskbased language learning: Old approach, new style. Profile: Issues in Teachers' Professional Development, 12(2), 165-178.

Rodríguez, C. \& Quintrileo, C. (2016). Las potencialidades ilocutivas de las conjugaciones verbales en español: Una paráfrasis crítica y propositiva de "La enseñanza del verbo en la educación básica" de Hernán Urrutia. Estud.pedagóg., 42, 137-149.

Searle, J. (1969). Speech acts: An essay in the philosophy of language. Cambridge, UK: Cambridge University Press.

Trillos, M. (2002) Prolegómenos lingüísticos para la enseñanza de lenguas en contextos multilingües

Colombianos. En enseñanza de lenguas en contextos multiculturales, memorias- seminario taller. Universidad del Atlántico.
Van den Branden, K. (2006). Task based language education. From theory to practice. Cambridge, UK: Cambridge University Press.

Vigil, N. (2006). Pueblos Indígenas y escritura. Retrieved from http://interculturalidad.org/numero03 /2_07.htm

Willis, J. (1996). A framework for task-based learning. Harlow: Longman.

Willis D. \& J. Willis (2007) Doing taskbased teaching. Oxford, UK: Oxford University Press.

Yang, J. (2015). El género gramatical en una gramática del español como segunda lengua. (Doctoral dissertation, Universidad Complutense de Madrid).

Yeasmin, S. \& Ferdousour, R. (2012).

Triangulation research method as the tool of social science research. Retrieved from http://www.academia.edu/701943/Tr iangulation_Research_Method_as_th e_Tool_of_Social_Science_Research 
